\title{
OPTIMALISASI BUDIDAYA DAN DIVERSIFIKASI PRODUK TURUNAN IKAN LELE
}

\author{
Listiorini $^{*}$; Yani Suryani ${ }^{2}$; Desi Ika ${ }^{3}$ \\ Prodi Akuntansi STIE Harapan Medan \\ Jalan Imam Bonjol No. 35 Medan \\ *Penulis Korespondensi: rini66@yahoo.com
}

\begin{abstract}
Abstrak
Tujuan dilaksanakannya Ipteks Bagi Masyarakat Kelompok Usaha Budidaya dan Pengasapan Ikan Lele ini diharapkan seluruh peserta pembinaan memahami pentingnya pemberdayaan potensi dirinya, dapat menyusun pembukuan usahanya, dapat menyusun proposal kelayakan, dapat mengelola modal usaha dengan baik, dapat membedakan keuangan usahanya dan rumah tangganya, dapat meningkatkan pendapatan kelompok usaha. Metode pelaksanaan kegiatan pengabdian terdiri dari ceramah, demonstrasi, praktek dan pendampingan. Hasil dari kegiatan pengabdian ini adalah dapat memberdayakan potensi peserta pembinaan, peserta pembinaan dapat menyusun pembukuan dan proposal kelayakan usaha, meningkatkan pengetahuan tentang pengelolaan modal dan cara pembenihan ikan yang baik serta menghasilkan buku panduan praktis pengelolaan laporan keuangan untuk UMKM.
\end{abstract}

Kata Kunci : Diversifikasi Produk, Ikan Lele, Optimalisasi Budidaya.

\begin{abstract}
[Optimization Of Culture And Diversified Products Derived Catfish.] The objective of science and technology to the Community Business Group Cultivation and Curing Catfish is expected that all participants of the coaching understand the importance of empowering themselves, may make bookkeeping business, can develop proposals eligibility, can manage capital well, can distinguish between financial businesses and households, could increase income business group. The method of implementation service activities consist of lectures, demonstrations, practice and mentoring. The results of service activities are able to empower potential participants coaching, coaching participants can arrange bookkeeping and feasibility of proposals, increased knowledge about capital management and how good fish hatcheries and produce a practical handbook for SMEs management financial statements.
\end{abstract}

Keywords: Diversified Product, Catfish, Diversified Product, Optimizing Of Culture.

\section{Pendahuluan \\ Latar Belakang}

Perikanan budidaya merupakan salah satu sumber daya yang penting untuk memenuhi kebutuhan masyarakat dan memiliki potensi untuk dijadikan penggerak perekonomian nasional. Seiring dengan program pembangunan kelautan dan perikanan tahun 2015 yang menjadikan pengelolaan sumber daya perikanan budidaya sebagai salah satu programnya sesuai dengan Permen Kelautan dan Perikanan Nomor 39/Permen - KP/2014. Peningkatan produksi perikanan dilakukan dengan tujuan untuk pemantapan ketahanan pangan dan gizi, peningkatan daya saing dan nilai tambah produk, pengelolaan sumber daya, peningkatan kesejahteraan masyarakat, peningkatan kompetensi dan kapasitas SDM serta inovasi ilmu pengetahuan dan teknologi kelautan dan perikanan. Seiring dengan peningkatan produksi perikanan budidaya Provinsi
Sumatera Utara, Kota Binjai sebagai salah satu kota penghasil ikan lele di Provinsi Sumatera Utara yang memiliki luas 9.023,62 Ha (+/- 90,23 Km2) yang terdiri dari 5 (Lima) Kecamatan yaitu Kecamatan Binjai Kota, Kecamatan Binjai Utara, Kecamatan Binjai Timur, Kecamatan Binjai Barat dan Kecamatan Binjai Selatan dan 37 (tiga puluh tujuh) Kelurahan serta mempunyai penduduk sebanyak 252.652 jiwa memberikan kontribusi dalam peningkatan produksi perikanan budidaya Provinsi Sumatera Utara khususnya khususnya perikanan air tawar di Kota Binjai cukup menjanjikan (KKP, 2012).

Kelompok budidaya ikan (POKDAKAN) TERATAI, merupakan kelompok masyarakat di Kelurahan Sumber Mulyorejo, Kecamatan Binjai Timur, Kota Binjai, yang memiliki sentra produksi pembenihan dan pembesaran ikan konsumsi. Saat ini jenis kegiatan yang dijalankan oleh kelompok ini 
meliputi pembenihan ikan lele, pembesaran berbagai jenis ikan air tawar seperti lele, nila, gurami. Lingkungan alam dan masyarakat di Kelurahan Sumber Mulyorejo sangat menunjang untuk pengembangan kegiatan budidaya ikan baik benih maupun konsumsi. Namun Kemampuan SDM kelompok ini dalam bidang perikanan masih kurang karena tidak ditunjang dari bidang ilmu perikanan, hanya berdasarkan pengalaman dan pelatihan ataupun penyuluhan dari dinas terkait.

Seiring dengan perkembangan budidaya ikan lele, para petani pembudi daya dihadapkan pada berbagai permasalahan diantaranya kenaikan harga pakan yang terjadi yang disebabkan menguatnya nilai tukar dollar AS sehingga kegiatan budidaya ikan beralih dengan menggunakan pakan dari alam, yang akan menurunkan kualitas dan menghambat laju pertumbuhan ikan yang dihasilkan. Seiring dengan perkembangan usaha, masalah lain yang dihadapi adalah ketika hasil panen tidak seluruhnya terserap pasar yang menyebabkan sisa ikan yang tidak terjual harus dipelihara lagi, tentunya akan berdampak pada biaya pemeliharaan untuk pakan dan perawatan. Hal ini dapat diatasi dengan cara menjalin kerjasama dengan pengusaha makanan olahan yang berbahan baku ikan lele, contohnya dengan usaha pengasapan ikan lele yang sangat prospektif di kota Binjai. Kegiatan usaha pengasapan ikan lele ini merupakan peluang usaha yang dapat dikembangkan dan menjadi salah satu bentuk diversifikasi usaha mikro bagi masyarakat.

Salah satu kelemahan dalam mengembangkan usaha pengasapan ikan lele ini terbentur pada keterbatasan modal, proses pengolahannya masih sederhana dan menggunakan alat tradisional. Tidak tersedianya alat pengemas otomatis yang dapat menyebabkan biaya produksi dari segi packaging relatif cukup tinggi. Pemasaran termasuk kegiatan promosi dan managemen yang masih sederhana turut menjadi faktor kelemahan pengembangan usaha pengasapan ikan lele.

Baik kelompok pembudidaya ikan lele yang sudah tergolong sebagai skala usaha yang besar maupun kelompok usaha pengasapan ikan lele, pengelolaan usahanya masih dilakukan secara sederhana termasuk dalam pengelolaan keuangannya yang belum dapat memisahkan antara keuangan untuk kegiatan usahanya dengan keuangan rumah tangganya walaupun sudah menggunakan bantuan buku pencatatan keuangan. Dengan demikian, laporan keuangan perlu diperbaiki sehingga sesuai dengan kaidah akuntansi dan mampu menjadi dasar bagi pengajuan tambahan modal ke perbankan. Pengelolaan keuangan menjadi salah satu aspek penting untuk kemajuan perusahaan.

Berikut adalah permasalahan yang dihadapi oleh kedua mitra antara lain yaitu tingginya biaya produksi ikan yang disebabkan karena meningkatnya harga pakan dan tingginya harga benih ikan dapat menurunkan semangat masyarakat dalam membudidayakan ikan lele, terutama jika tingginya biaya produksi ini tidak diikuti dengan kenaikan harga jual ikan lele. Demikian juga dengan usaha pengasapan ikan lele, proses produksi yang dilakukan masih sangat sederhana baik pada proses pengolahan maupun packaging menjadi penyebab tingginya biaya produksi; tidak memiliki pengetahuan, kemampuan dan sarana untuk membuat sendiri pakan yang berkualitas untuk menurunkan biaya produksi; keterbatasan modal dan keterbatasan pengetahuan tentang pengelolaan modal usaha; Proses pengolahan ikan lele asap (sale lele) masih sangat sederhana dan menggunakan alat tradisional. Begitupun dengan ikan lele asap belum memiliki kemasan; tidak memiliki pengetahuan pembukuan yang memadai, baik usaha budi daya ikan lele maupun usaha pengasapan ikan lele memiliki keterbatasan pengetahuan dalam menyusun pembukuan usahanya; pemasaran termasuk kegiatan promosi dan pengelolaan usaha masih sederhana.

Berdasarkan analisis masalah di atas, maka tujuan pelaksanaan pengabdian ini adalah dapat meningkatkan pemahaman dan kesadaran mitra untuk memberdayakan potensi yang dimiliki masing masing mitra; meningkatkan kemampuan mitra dalam menyusun pembukuan usahanya dengan baik dan meningkatkan kemapuan mitra dalam menyusun proposal kelayakan usaha untuk mendapatkan pinjaman perbankan sehingga dapat mengembangkan usahanya; meningkatkan kemampuan mitra dalam mengelola modal usaha dengan baik, dapat membedakan keuangan usahanya dan keuangan rumah tangganya; dapat meningkatkan pendapatan kelompok usaha dan dapat menghasilkan produk ikan lele asap yang sehat dan higienis serta tahan lama; menghasilkan buku panduan praktis pengelolaan keuangan bagi UMKM.

\section{Metode}

Adapun tahapan kegiatan dalam pelaksanaan pengabdian ini terdiri dari tahapan survey, tahapan pelaksanaan, tahapan monitoring dan evaluasi. Dalam tahapan pelaksanaan pelatihan digunakan metode ceramah, demonstrasi, latihan atau praktek dan pendampingan. Tahapan survey meliputi peninjauan lokasi pengabdian pada kedua kelompok yaitu POKDAKAN Teratai dan Kelompok Ternak Tani Jaya dan identifikasi kebutuhan dari kedua kelompok tersebut.

Pada tahapan pelaksanaan pelatihan, metode ceramah digunakan untuk menyampaikan teori dan konsep-konsep dasar-dasar pencatatan transaksi, penyusunan laporan keuangan baik laporan laba rugi, neraca serta pengetahuan pengemasan produk yang higienis dan sehat serta cara pembenihan yang dapat menghasilkan benih yang berkualitas. Materi cara pembenihan yang baik dilaksanakan bekerjasama dengan Dinas Kelautan dan Perikanan Kota Binjai. Pada metode demonstrasi diberikan contoh bagaimana mencatat transaksi usaha dan menyusun laporan keuangan secara manual berupa persamaan akuntansi. Sumber daya yang dimiliki oleh suatu organisasi atau perusahaan disebut dengan aset. Sedangkan hak atau klaim atas aset perusahaan dibagi menjadi 2 (dua), yaitu: (1) hak kreditor, (2) hak pemilik. Hubungan antara keduanya, dapat dinyatakan dalam suatu persamaan yang disebut dengan persamaan dasar 
akuntansi dan ditulis sebagai berikut (Kieso et al., 2008). Aset $=$ Kewajiban + Ekuitas. Sedangkan metode latihan atau praktek, peserta mempraktekkan secara optimal bagaimana melakukan pencatatan transaksi usaha berupa penyusunan laporan keuangan yang perlu disusun untuk usaha kecil secara umum yaitu Neraca, Laporan Laba/Rugi, dan Laporan Arus Kas. Dan kegiatan praktek pengemasan produk yang higienis dan sehat. Tahapan monitoring dan evaluasi, tim pengabdian melaksanakan kegiatan pendampingan dan evaluasi pasca tahapan pelaksanaan kegiatan pengabdian.

\section{Pembahasan}

Hasil kegiatan pengabdian pada masyarakat yang telah dilakukan secara garis besar mencakup beberapa komponen, yaitu keberhasilan target jumlah peserta pelatihan, ketercapaian target materi yang telah direncanakan, ketercapaian tujuan pelatihan dan kemampuan peserta dalam penguasaan materi. Ketercapaian target jumlah peserta dapat dilihat dari jumlah peserta yang ditargetkan adalah 20 orang dan pada kenyataannya kegiatan diikuti oleh 25 orang sehingga target jumlah peserta telah dapat terpenuhi. Semua peserta dapat mengikuti seluruh proses pelatihan dari awal sampai selesai, kegiatan yang dirancang $100 \%$ terlaksana.

Target penyampaian materi pelatihan juga tercapai karena materi dapat disampaikan secara keseluruhan. Dengan demikian maka tujuan kegiatan pengabdian pada masyarakat dapat terpenuhi. Penguasaan kompetensi peserta pelatihan dievaluasi melalui praktek mandiri pengelolaan usaha. Dari 25 peserta pelatihan, hanya beberapa orang saja yang telah melakukan pencatatan transaksi usaha dan telah melanjutkannya dengan penyusunan laporan keuangan (laporan rugi laba dan neraca). Selain itu peserta juga telah berusaha untuk membedakan antara pengeluaran pribadi dengan pengeluaran usaha dan dapat menghitung berapa omzet dan laba yang diperoleh sehingga kemungkinan mengalami kerugian akan semakin kecil, serta memanfaatkan informasi dari laporan keuangan tersebut untuk melakukan proyeksi usaha di masa depan.

Praktek Pelatihan penyusunan proposal kelayakan usaha bagi POKDAKAN Teratai dan Kelompok Ternak Tani Jaya dilakukan dengan tujuan agar masing - masing peserta dapat menyusun sendiri proposal kelayakan usaha yang nantinya akan mempermudah pihak perbankan melakukan penilaian terhadap kelayakan usaha, khususnya untuk usaha mikro, kecil dan menengah, proposal kelayakan usaha tersebut memuat beberapa aspek antara lain, Aspek Umum dan Legalitas, Aspek Manajemen, Aspek Teknis dan Produksi, Aspek Pemasaran dan Aspek Keuangan.

Kegiatan berikutnya adalah pemberian alat-alat dan pembuatan kolam. Alat - alat yang dibutuhkan oleh mitra pengabdian pengusaha pengasapan ikan lele yaitu: lemari asap, alat packing plastik (handsealer), plastik untuk pengemasan dan label. Lemari asap diberikan agar proses pengasapan ikan lele dapat menghasilkan produk ikan lele asap yang berkualitas dan higienis. Pengemasan dilakukan dengan menggunakan plastik bening yang bersih dan kuat, lalu kemasan tersebut harus divakum dan diberi label. Perbaikan dalam kemasan ikan lele asap akan menghasilkan produk ikan lele asap yang sehat dan higienis serta tahan lama dan akhirnya konsumen lebih tertarik dan meningkatkan minat konsumen untuk membeli. Dengan demikian diharapkan akan meningkatkan penjualan ikan lele asap tersebut. Pembuatan kolam pembenihan ikan lele sebanyak 3 unit dengan ukuran 4,5 x 1,5 m2 dan pemberian alat tabung oksigen dan regulator serta pembuatan kolam pembenihan yang memiliki sirkulasi air dengan pipa untuk air keluar dan air masuk yang dilengkapi dengan airator untuk sirkulasi udara untuk kelompok Pokdakan Teratai.

Kolam pembenihan ini dibuat di atas tanah milik Mitra I yaitu Bapak Joni Sudarta di Kelurahan Sumber Mulyorejo Kec. Binjai Timur. Pembuatan ini dimaksudkan agar setiap anggota meningkatkan produksi benih dan dapat mempermudah penanggulangan hama dan penyakit. Selanjutnya tim pengabdian menyusun buku panduan praktis pengelolaan laporan keuangan untuk UMKM. Hal ini dilakukan dengan harapan agar buku ini dapat menjadi buku pedoman bagi para pelaku usaha mikro agar dapat membuat laporan keuangan yang baik guna mendukung pengajuan kredit usaha di bank.

Berdasarkan evaluasi pelaksanaan kegiatan dapat diidentifikasi faktor pendukung dalam pelaksanaan program pengabdian kepada masyarakat adalah adanya kerjasama yang baik antara tim pengabdian dengan mitra POKDAKAN Teratai dan Kelompok Tani Jaya; partisipasi aktif dan antusiasme yang tinggi dari anggota POKDAKAN Teratai dan Tani Jaya dalam mengikuti seluruh rangkaian kegiatan.

Selain itu dalam pelaksanaan pengabdian pada masyarakat ini juga ada beberapa hal yang dipandang sebagai kendala pelaksanaan yaitu latar belakang anggota POKDAKAN Teratai yang sangat bervariasi sehingga pemahaman para peserta terhadap materi sangat bervariasi; beberapa peserta pelatihan belum memiliki pengetahuan awal tentang pencatatan transaksi sehingga mengalami kesulitan dalam praktek penyusunan laporan keuangan.

\section{Penutup \\ Kesimpulan}

Kegiatan pengabdian IbM Kelompok Usaha Budidaya Ikan Lele dan Kelompok Usaha Pengasapan Ikan lele di Kota Binjai telah dilaksanakan dengan baik dan tanpa halangan yang berarti. Dengan kerjasama tim pengabdian yang baik serta peran aktif dari peserta dan penyuluh / narasumber dalam kegiatan pengabdian ini maka semuanya telah berjalan sesuai yang diharapkan. Kegiatan ini diharapkan dapat memberikan manfaat bagi mitra pengabdian masyarakat dalam keberlanjutan usaha dari kedua mitra sehingga permasalahan yang dihadapi mitra dapat segera diatasi, dapat meningkatkan pendapatan dan pengetahuan kedua mitra. 
Pengabdian yang kami lakukan ini antara lain telah dilaksanakannya kegiatan pelatihan tentang teknik penyusunan pembukuan sederhana, penyusunan proposal kelayakan usaha, pengelolaan modal dan cara pembenihan ikan yang baik. Dengan adanya kegiatan pelatihan ini diharapkan terjadi peningkatan kemampuan mitra dalam hal manajemen usaha dan pembukuan yang bermanfaat dalam menjalankan usaha.

Pemberian alat-alat yang dibutuhkan oleh mitra pengabdian pengusaha pengasapan ikan lele yaitu: lemari asap, alat packing plastik (handsealer), plastik untuk pengemasan dan label serta pembuatan kolam pembenihan ikan lele sebanyak 3 unit dengan ukuran 4,5 x 1,5 m2. Dan telah disuusun buku panduan praktis pengelolaan laporan keuangan untuk UMKM.

\section{Saran}

Berdasarkan evaluasi yang telah dilakukan dapat diajukan beberapa saran sebagai berikut: perlu adanya kegiatan pelatihan lanjutan secara periodik, berkelanjutan untuk terus mengembangkan kelompok usaha budidaya ikan lele dan pengasapan ikan lele terutama dalam hal teknis budidaya ikan serta pelatihan lanjutan lainnya di bidang akuntansi serta perlu adanya pendampingan dari instansi terkait (Dinas Pertanian dan Perikanan Kota Binjai) agar usaha yang selama ini dikelola oleh POKDAKAN Teratai dan Kelompok Tani Jaya dapat terus maju dan membantu kemakmuran anggotanya.

\section{Daftar Pustaka}

Peraturan Menteri Kelautan dan Perikanan Republik Indonesia Nomor 39/Permen - KP/2014 Tentang Rencana Kerja Kementrian Kelautan dan Perikanan Tahun 2015. Kelautan dan Perikanan Dalam Angka 2013.

KKP, (2012) Analisis dan Data Pokok Kelautan dan Perikanan Menurut Propinsi Tahun 2012

Purnomo, Setyawan. 2007. Menumbuhkan Kebiasaan Menyusun Laporan Keuangan pada Usaha Kecil dan Menengah. Universitas Negeri Jakarta

Kieso, Donald E., Weygandt, Jerry J., dan Terry DW.(2008). Akuntansi Menengah. Edisi Bahasa Indonesia. Edisi Kesepuluh.Jakarta: Erlangga.
Foto Kegiatan :

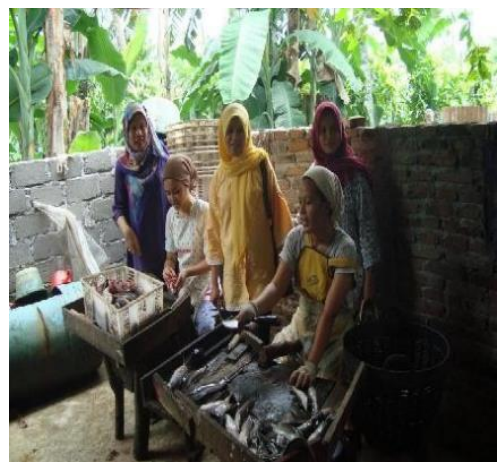

Gambar 1.: Survei awal ke Lapangan (Usaha pengasapan ikan Lele)

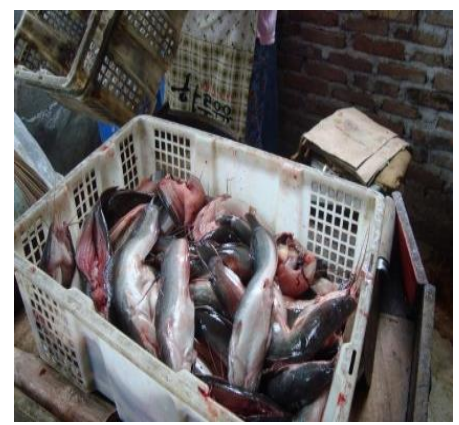

Gambar 2 : Proses Pembuatan Ikan lele

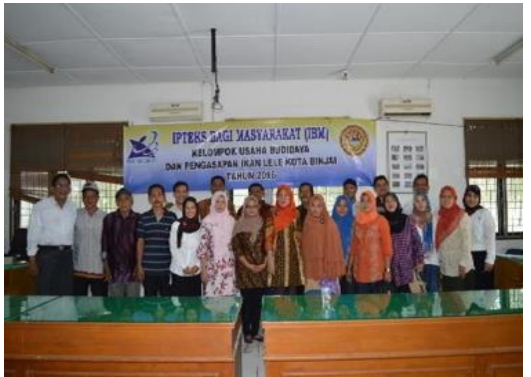

Gambar 3 : Foto Bersama Peserta dan Pemateri Pelatihan

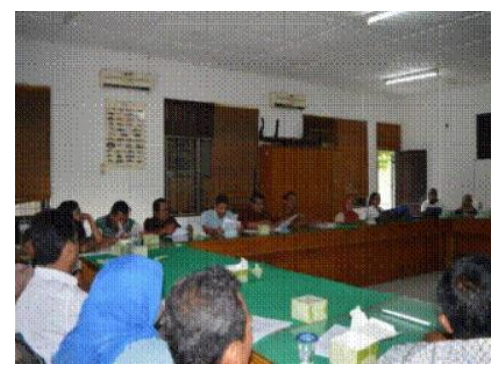

Gambar 4

Diskusi Pelatihan Teknik 


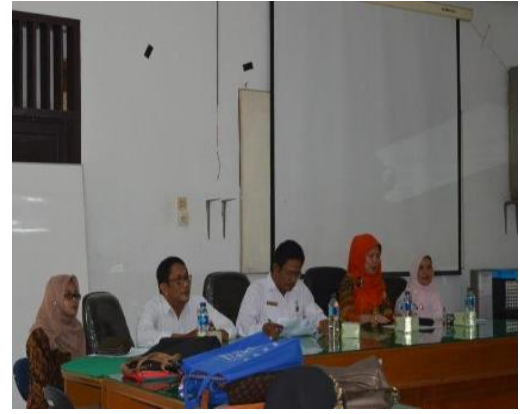

Gambar 5 : Pelatihan Penyusunan Pembukuan Sederhana, Proposal Kelayakan Usaha dan Pengelolaan Modal Usaha

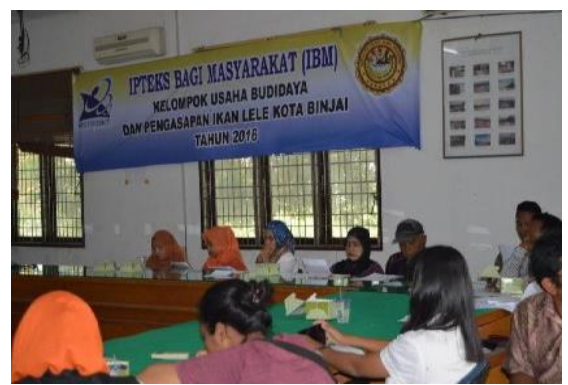

Gambar 6 : Pelatihan Penyusunan Pembukuan Sederhana

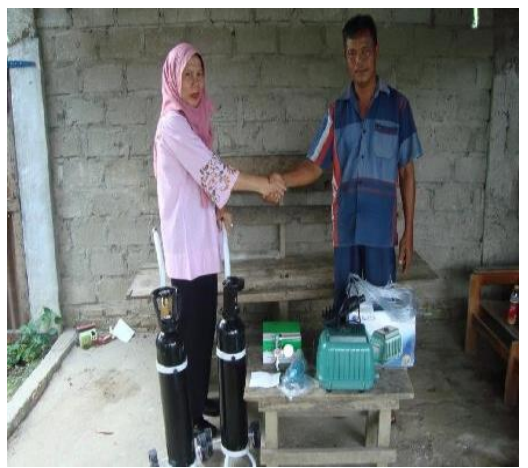

Gambar 7: Penyerahan Tabung Oksigen beserta troli, Airpumps, Selang, dan Regulator Oksigen

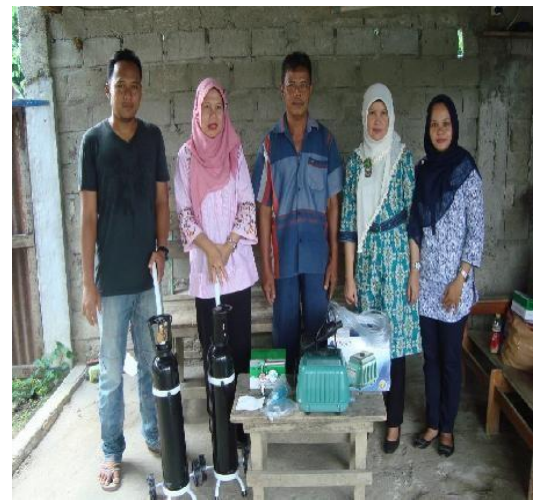

Gambar 8 : Foto Bersama Penyerahan Tabung Oksigen beserta troli, Airpumps, Selang, dan Regulator Oksigen

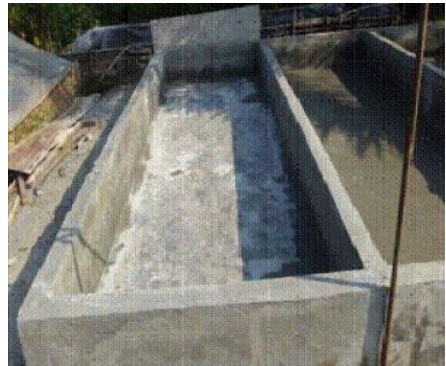

Gambar 9 : Kolam Pembenihan ikan lele

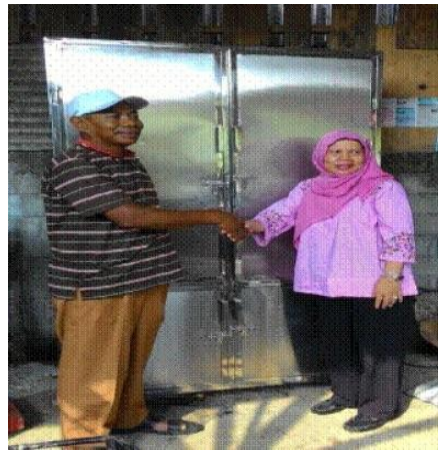

Gambar 10: Penyerahan Lemari Pengasapan Ikan Lele (Oven)

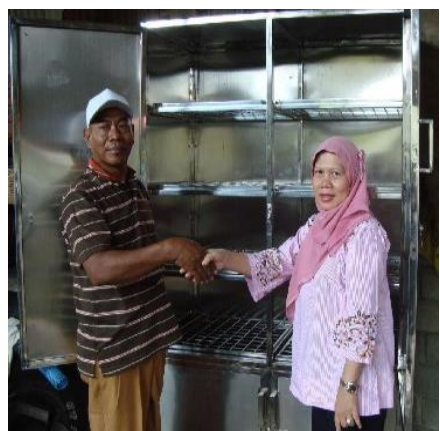

Gambar 11 : Penyerahan Lemari Pengasapan Ikan Lele (Oven)

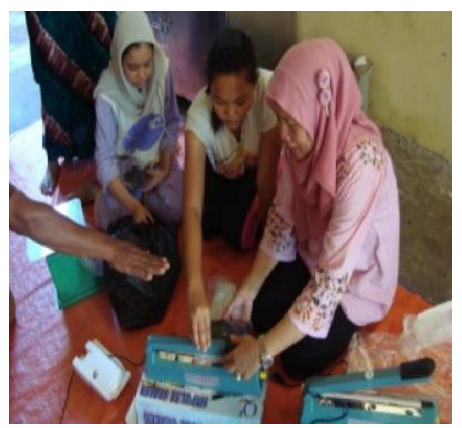

Gambar 12 : Demo Pemakaian Label, Plastik Packing, HandSealer 


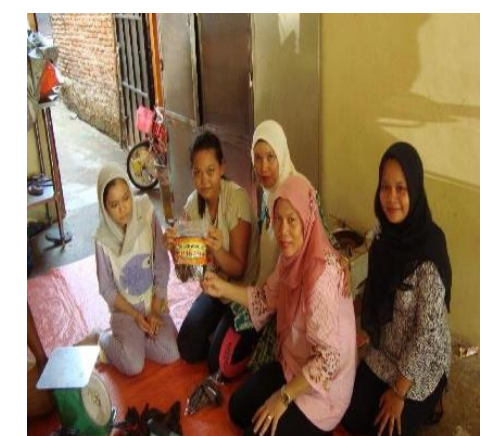

Gambar 13: Hasil Pemakaian Label, Plastik Packing, HandSealer

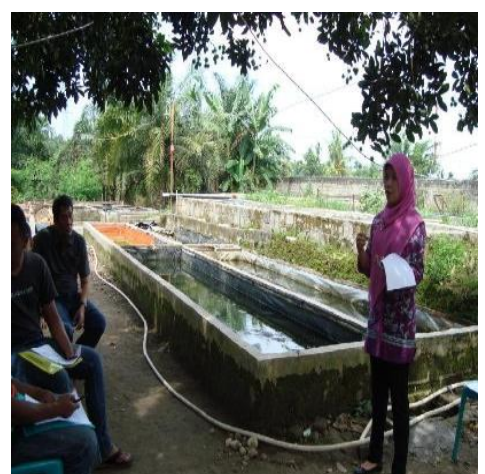

Gambar 14 : Pendampingan kegiatan penyusunan pembukuan sederhana 